\title{
'CITTASLOW': AN ALTERNATIVE MODEL FOR LOCAL SUSTAINABLE DEVELOPMENT OR JUST A MYTH? EMPIRICAL EVIDENCE IN THE CASE OF TARAKLI (TURKEY)
}

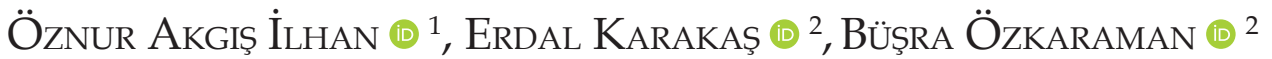 \\ ${ }^{1}$ Department of Geography, Ahi Evran University, Kırşehir, Turkey \\ ${ }^{2}$ Department of Geography, Bilecik Şeyh Edebali University, Bilecik, Turkey
}

Manuscript received: January 10, 2020

Revised version: September 24, 2020

\begin{abstract}
İlhan Ö.A., KarAKaș E., ÖZKARAMAN B., 2020. 'Cittaslow': An alternative model for local sustainable development or just a myth? Empirical evidence in the case of Tarakli (Turkey). Quaestiones Geographicae 39(4), Bogucki Wydawnictwo Naukowe, Poznań, pp. 23-37. 1 table, 3 figs.

ABSTRACT: This research attempts to answer whether Cittaslow is a myth or an effective model for development for Taraklı, a small town in the Sakarya province of Turkey. The study was designed and analysed using the mixed method research model. The results are as follows. Since Taraklı became a Cittaslow, the number of tourists increased which ultimately helped to fight against unemployment and also increased income of people. Women's participation in the labour force had increased and their representation in public places was enhanced. Important steps were taken towards the preservation of cultural heritage. Along with quantitative and qualitative improvements in green areas, the local people's awareness of environmental protection has increased.
\end{abstract}

KEYwORDS: Cittaslow, sustainable development, slow tourism, Taraklı, Turkey

Corresponding author: Öznur Akgiş İlhan, Department of Geography, Faculty of Arts and Sciences, Ahi Evran University, Terme Cad., Kırşehir, ZIP Code: 40100, Turkey; e-mail: oznrakgis@gmail.com

\section{Introduction}

Undoubtedly, one of the most popular concepts in this cotemporary world is globalisation. This concept is used as a password, a magic word, or as a concept that will open the door to all the mysteries of the past and the future. Some believe that people cannot thrive without globalisation; while for others, it is the reason for existing dissatisfaction in the society (Bauman 2012). However, there is consensus that the effects of this process have clearly accelerated and standardised human life (Bekar et al. 2015) and have also increased environmental degradation. Based on this context, a number of philosophies and movements have emerged as a reaction or solution to this process, which leads to the ambiguity of social and spatial identities (Petrini 2001), blurring of cultures and an increase in environmental problems.

Slow Food is one of such philosophies. The movement, which emerged as a protest movement against the opening of McDonald's fastfood outlets in Italy in the 1980s, has now transcended national boundaries by turning into a unique network (Heitmann et al. 2011). Although the early focus was on food, today it has become a philosophy with sustainability-oriented goals 
such as promotion of cultural identities (Petrini 2001; Radstrom 2011) and preserving natural resources through rational use and safeguarding biodiversity by generating income continuously from them (Mayer, Knox 2006; Nilsson et al. 2007; Heitmann et al. 2011). Slow cities (Cittaslow), a movement developed from the philosophy of Slow Food, is aimed at achieving these goals in order to cover all aspects of urban life. Nowadays, this movement is treated as an alternative model for local sustainable development in small cities by many researchers in development studies (Mayer, Knox 2006; Pink 2008; Semmens, Freeman 2012; Baldemir et al. 2013; Ekinci 2014; Karabağ et al. 2012).

In fact, neither Slow Food nor Cittaslow movements attempts to create development directly. It should be remembered that when this movement started, together with Slow Tourism, it gradually caught more attention as a local sustainable model (Heitmann et al. 2011). Further, as stated by Hall (2006) in Culinary tourism and regional development: From slow food to slow tourism?, slow tourism is an expected result of the development of the Slow Food movement (Hekimci 2014; Nilsson et al. 2007; Nilsson et al. 2011).

Slow tourism is defined as a trip that enables self-realisation of being slow in behaviour and thinking, thereby observing the experience caused by the target more closely (Sugiyama, Nobuoka 2007). According to Heitmann et al. (2011), slow tourism is a form of tourism that gives importance to diversity, local cultures, history and environment rather than quantity during travel. It is characterised by the pleasure of discovery, learning and sharing. Although slow movements and slow tourism are closely related, it is not possible to reduce the dynamism that creates slow tourism only to slow movements such as Cittaslow. Similar tourism movements can be created by creating public or private spaces where tourists can slow down and interact with nature (Howard 2012). There are numerous studies on slow tourism (Lumsdon, McGrath 2011; Lin 2017; Dickinson et al. 2011). In these studies, it has been emphasised that the Cittaslow movement and the accompanying slow tourism positively affect development. (Yurtseven, Kaya 2011; Presenza et al. 2015a; Presenza et al. 2015b; Park, Kim 2016; Başarangil, Ulaş 2017; Doyduk, Okan 2017; Batyk,
Woźniak 2019; Senetra, Szarek-Iwaniuk 2020). However, there is a clear need for affirmative, refuting, or interpretative studies in this area.

This study discusses the relationship between slow tourism and local sustainable development in Taraklı (located in Sakarya province, Turkey), which achieved the status of Cittaslow as it is one of the quietest Turkish cities. In this context, it was aimed at finding out whether the model of slow city is effective in achieving sustainable development. The study consists of four parts. Part 1 explains the Cittaslow philosophy and characteristics, and the role of a slow city in sustainable development. Part 2 gives information about Tarakl1, the area of research, and details including data, data collection instruments and evaluation of data. Part 3 is dedicated to the study's findings. The last part discusses and analyses whether the slow city concept constitutes a model for sustainable development based on the findings and results.

\section{Convergence of Slow City and local sustainable development philosophies}

Nowadays, each and everything is in motion and the speed of the motion is increasing. This is considered as an effective process in changing the conventional perception of time and space, and is referred to as time-space compression by Harvey (1989). Recent research also shows that people are gradually feeling the pressure of time more and more (Zuzanek 2004; Zuzanek, Smale 1997). As a result of the changing lifestyle, a number of new concepts such as scarcity of time, deepening of time, hastiness disease, time obsession, lack of time and time poverty have been added to the literature (Daly 2001). Also, slow movements led by various individuals and groups began to appear, which criticised the rapid urban lifestyle and practices. Moreover, the increase in the number of these movements reflects a desire in society for change and renewal (Botta 2016). Slow Food is one of them and has led to a number of movements including Slow Fish, Slow Art, Slow Parenting, Slow Education, Slow Home and Office, Slow Money, Slow Fashion and Slow Travel.

The Cittaslow movement has developed as both an urban social movement and a model for local governance which is an extension of the 
Slow Food movement (Pink 2008). Now, it has become a network consisting of 266 cities in 30 countries (www.slowfood.com).

It is possible to talk about a clear convergence between sustainable development and the Cittaslow movement. According to the Brundtland Report (WCED 1987), sustainable development is "development that meets today's needs without compromising the ability of future generations to meet their own needs". It is also defined as a development that balances economic, social and environmental areas. Accordingly, sustainable development can be described as being social, economic and environmentally good (UN 2015). Similar to the sustainable development approach, the Cittaslow philosophy aims to balance these three dimensions: social, economic and environmental (https://www.cittaslow. org/). The two approaches that are expressed in this sense are similar in their relation to the concept of development.

The basic and fundamental objective of the Cittaslow movement is the preservation of a city's authenticity (Radstrom 2011) based on the annual census of the typical products of the territory, ownership of local cultural diversity and values, establishment of markets for selling local products in certain parts of the city and the development of handicrafts (Mayer, Knox 2006). Accordingly, it can be said that protecting and developing cultural diversity is one of the most important goals in terms of the Cittaslow philosophy. It is especially emphasised that people are aware of the natural and cultural diversity of the world in the context of sustainable development goals. Further, it is also recognised that all cultures and civilisations can contribute to sustainable development and are important providers of sustainable development. Therefore, the emphasis on culture within the framework of sustainable development goals is also remarkable and similar to the Cittaslow philosophy.

Another emphasis is given to social life according to the Cittaslow charter, to protect the dependent population, such as young people and the elderly, and prevent disadvantaged groups from being exposed to social exclusion because of their ethnic or racial characteristics. Increasing the quality of life of these groups, characterised by disadvantageous features such as age, disability or being migrants, which are evaluated under the heading social cohesion in the charter, is one of the important development goals that is handled along with the concepts of equality and justice within the framework of sustainable development goals. Another effective component in the increase of social welfare is infrastructure. The Cittaslow charter infrastructure component is evaluated under the title of infrastructure policies and promotes the use of environmentally-friendly transport systems, vehicles and technologies. It is incorporated within the framework of 'transport, industry, transport and innovation' in sustainable development targets and is considered an important topic in ensuring environmental sustainability, in addition to social sustainability.

According to the Cittaslow philosophy, "Good living means having the opportunity of enjoying solutions and services that allow citizens to live their town in an easy and pleasant way" (https:/ / www.cittaslow.org/). So, Cittaslow cannot be reduced to an approach that aims only to protect cultural values. It also aims to increase and improve economic well-being in addition to cultural sustainability. For this reason, achieving economic sustainability draws attention as one of the other aims of the Cittaslow philosophy. As far as economic goals are concerned, these are related to high exposure of local products to the world by increasing production quantity, access to food and financing producers without compromising quality. Providing training to increase the quality of local products, establishing markets for them and planning accommodation capacities are the objectives under the category of quality of urban life policies and agricultural, touristic and artisan policies, which are related to economic development. In this context, targets based on economic support for producers and facilitating the accessibility of economic goods and opportunities are important in terms of ensuring economic development. The objectives of welcoming and accommodating tourists and promoting the destination, which are emphasised within the frame of 'policies for hospitality, awareness and training', are among the goals that will contribute to economic development. When these goals are evaluated as a whole, they are also aligned with sustainable development goals.

In addition to the socio-economic objectives mentioned above, Cittaslow also encourages a lifestyle which uses technologies to improve the 
quality of the environment. There is a clear emphasis on environmental sustainability across the entire Cittaslow charter. The Section 'energy and environmental policy' in the charter is directly related to environmental protection. Accordingly, the protection of air, water and soil quality, waste disposal and waste management stand out as the main targets in ensuring environmental sustainability. When the goals of affordable and clean energy, climate action, life under water and life on land, which are among the sustainable development goals, are examined, their basic compliance is similar to that of Cittaslow.

The Cittaslow movement is closely related to globalisation. For this reason, 'partnership', which is a policy of the Cittaslow philosophy, is the most important factor in achieving social, economic and environmental goals. When sustainable development goals are also examined, it can be seen that partnership is one of the basic objectives. In this sense, it is possible to say that there is a partnership between the two philosophies.

Considering all this, it is evident that there is a clear convergence between sustainable development and the Cittaslow philosophy. As stated by Semmens and Freeman (2012) too, this movement is considered as an alternative model for local sustainable development because it sets forth a philosophy that aims to revolutionise the urban age criteria.

\section{Data and methods}

\section{Study area}

The study area of Taraklı is located within Sakarya province, which is in the northwest of Turkey (Fig. 1). According to the Turkish Statistics Institute (TURKSTAT), the total population of Taraklı city was 6,849 in the year 2017 based on the Address-Based Population Registration System. While the total population of the district was 11,099 in 1990, the figure decreased to 9,212 in 2000. Population growth rate is $-8.28 \%$ with a tendency to decrease continuously.

The Cittaslow journey of Taraklı began in 2011. It has several features that justify the award

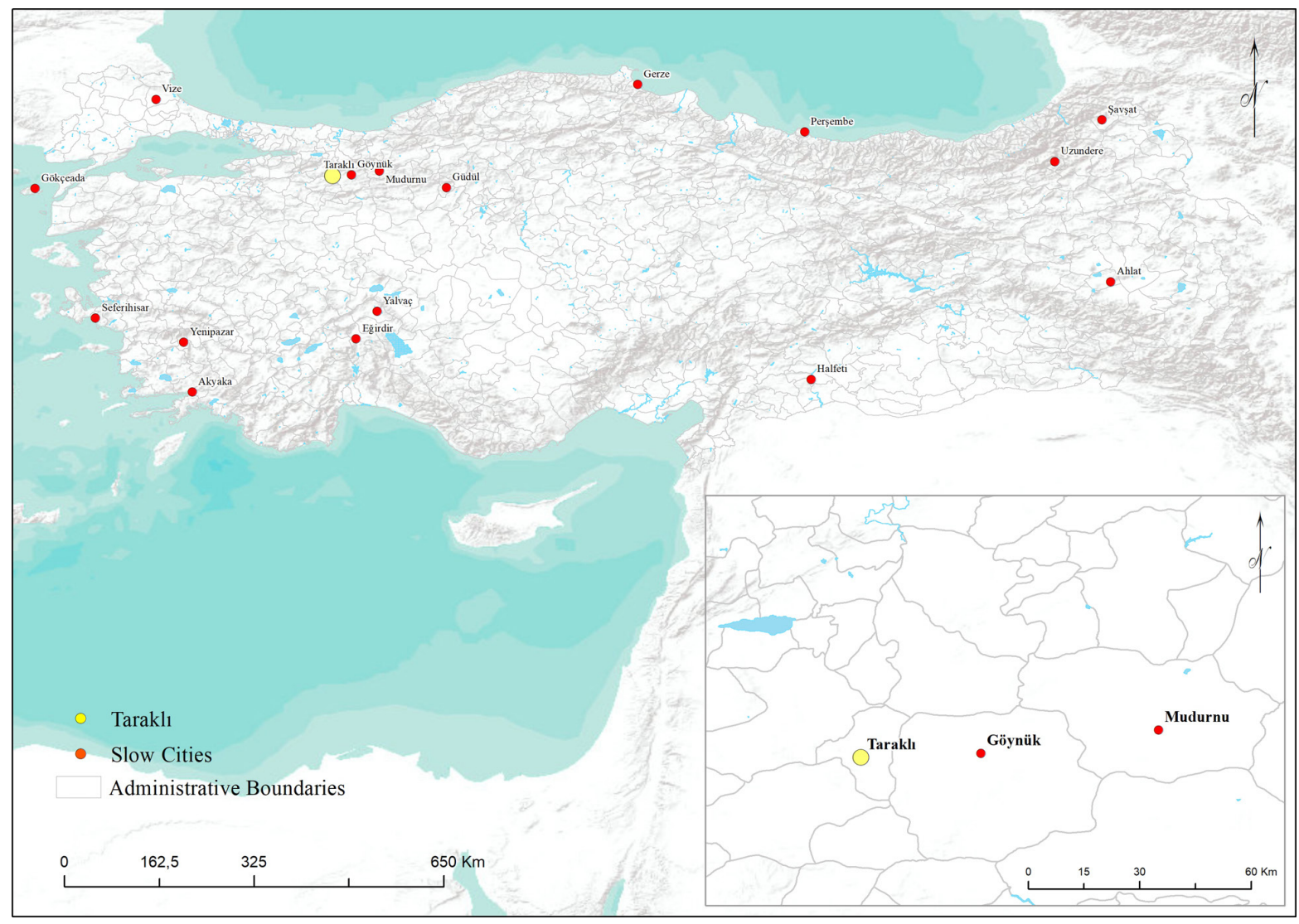

Fig. 1. Location of study area. Source: own elaboration. 
of the Cittaslow certificate. For example, there is no environmental pollution in the district since there are no industrial facilities, the tap water is clean enough for safe drinking, all households have a sewer infrastructure, energy-saving light bulbs are used for illumination of the town, the local farmers practice organic agriculture without using GMO (Genetically Modified Organisms) seeds, and there is no threat of electromagnetic, light and noise pollution in Taraklı. Moreover, old buildings are restored and it is planned to use environmentally-friendly vehicles to reduce carbon emissions in the future. Measures are being taken to facilitate the easy life of disabled persons in the public sphere, and a local market has been established for the sale of organic products (Değirmenci, Sarıbıyık 2015).

The main economic activities in the district are agriculture and related sectors and traditional handicrafts (Fig. 2). The most notable of traditional handicrafts are weaving, blacksmithing, and spoon and comb-making. While sericulture and weaving were the dominant economic activities in Tarakl1 and surrounding rural areas in the 1960s (Çavaç 2008), these have been largely lost due to the low-cost and mass production of recently-developed industries (Özkan 2008). Another traditional handicraft is blacksmithing performed by master blacksmiths and historical warlike items such as helmets, armour and shields are produced as well as candles, coffee tables, lanterns and axes decorated with animal figures (Aslan 2015). Production of spoons, which is one of the handicrafts produced in many parts of Anatolia, is also common in Taraklı. Making of combs is the most well-known handicraft that identified with the town of Tarakli to the extent that the town is called Tarakl (meaning comb making) because the majority of the population was engaged in comb and spoon making at that time according to the 17th century travel journal (Seyahatname) of Evliya Çelebi (Kan 2009). In fact, though currently the main income-generating activities are agriculture and animal husbandry, they continue the comb-making tradition in order to generate additional income.

Another important economic activity in Tarakl1 is tourism. Thermal tourism stands out as the most notable in this sector. In addition, since the district was announced to be a slow city, developments have taken place in slow tourism and the number of tourists visiting the city has increased (Taraklı Municipality 2017).

\section{Research design}

This study focuses on the role played by the slow tourism movement in sustainable development, which is a result of its status 'Cittaslow'. In this regard, the effect of being a slow city in local sustainable development has been evaluated from the perspective of both tourists and locals.

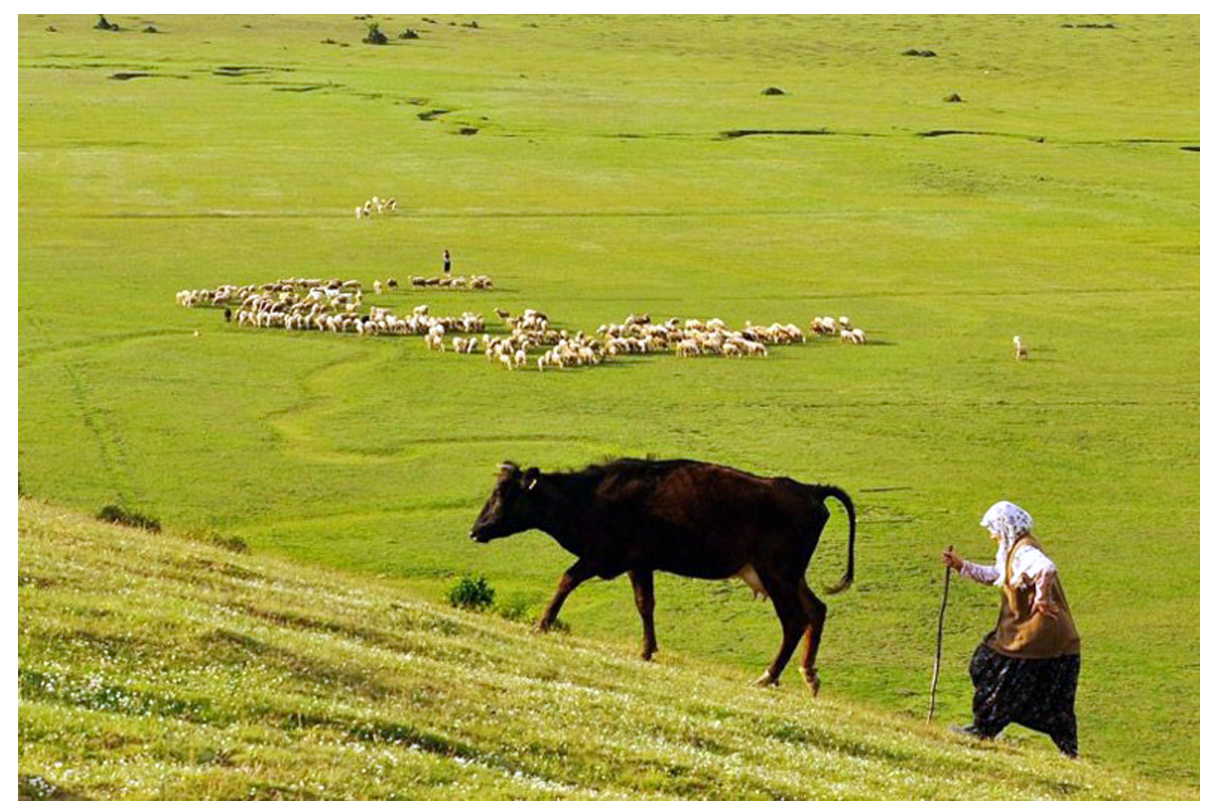

Fig. 2. Traditional livestock activities in the study area. Source: picture taken by authors. 
Sustainable development is measurable or quantifiable in terms such as quantity, scope, density, or frequency. In other words, it can be assumed to be compatible with positivist epistemology. However, the inadequate number of theories in the literature on the relationship between Cittaslow and sustainable development hinders the verification of measurement factor and restricts the possibility of comparison. For this reason, although the study topic seems to be compatible with positivist epistemology at first, the study is also aligned with conventionalist or semantic epistemology because of these limiting factors. Therefore, the role of Cittaslow status in sustainable development was evaluated not only with quantitative research techniques using empirical data and focusing on cause and effect relations, but also with the qualitative research technique.

It was decided that the most appropriate research method was the mixed method research design (Fig. 3). Mixed-method research is accepted as a third method in addition to qualitative and quantitative research, and it bridges these two methods (Creswell 2009). This method, combined with the other two methods, provides a better understanding of the research problem (Creswell, Clark 2007). Cittaslow, slow tourism and local sustainable development is a bilateral problem experienced not only by the local community but also by tourists. For this reason, data needed to be obtained from both local people and tourists on the subject being researched.

The quantitative method was employed to reveal the relationship between Cittaslow and local sustainable development based on the perspective of tourists. It was considered that

\begin{tabular}{|c|}
\hline Mixed Research Methods \\
\hline \hline \multicolumn{1}{|c|}{ Sequential (Qualitative-Quantitative) } \\
Exploratory Design
\end{tabular}

Fig. 3. Research pattern. Source: own study. quantitative data collection and analysis tools would be more functional in determining the impact of Cittaslow as a motivation for tourists' destination preferences. Moreover, quantitative tools are also considered to be more practical in determining the expenditure of tourists on accommodation, food and shopping and the impact of these expenditures on the local economy.

According to the municipality of Tarakl1, approximately 100,000 tourists visit the district every year. Some of them come to enjoy the thermal facilities in the district and others for the simple reason of wanting to visit a peaceful city. The number of tourists motivated by the latter is not known; therefore, the sample was calculated based on the total number of tourists, by using the stratified sampling method. Considering a confidence level of $99 \%$ and error margin of $10 \%$, it was decided to conduct surveys with 166 people. However, a total of 181 people were surveyed if the missing data in December, January and February of 2018 were considered. Surveys were conducted by face to face discussions.

The participants consisted of $62.4 \%$ women and $37.6 \%$ men. Of these, $44.8 \%$ were married and $55.2 \%$ single. They were heterogeneous in education level such that $5 \%$ of the participants had completed primary school, $6.1 \%$ primary and secondary school, $24.3 \%$ high school, $59.9 \%$ university and $7.7 \%$ had a postgraduate degree. The average age was 30 and the average income was $\$ 567$. When occupation is considered, $85 \%$ of the participants belonged to the group of workers, students and civil servants, while $15 \%$ belonged to the group of housewives, retirees, tradesmen and self-employed.

The qualitative method was used to determine the Cittaslow and sustainable development relationship through the eyes of the locals. There was little empirical evidence for the impact of changes brought about by Cittaslow certification on the local community. This factor limits our research in developing a generalisable measurement tool for the whole concept and for this reason qualitative data collection and analysis tools were preferred.

In order to elaborate the findings obtained from quantitative data, the qualitative interviews were conducted with 11 people using a semi-structured questionnaire. This group comprised of three female and eight male participants 
aged from 22 to 49 . There were five tradesmen, one tailor, one veterinarian, one public relations specialist and two students, but one participant was unemployed. In spite of finding the increase in the visibility and participation of local women in public space in the study area, their social network and capital are found to be low. So, requests for interviews were not received positively by the majority of women. The main difference in the gender distribution of interviewees is because of this. Interviews with local people were held face to face.

\section{Results}

\section{Quantitative results}

It was found that $44 \%$ of the surveyed tourists made day trips to the district and the rest $(56 \%)$ planned to stay for 1 day or more. Accommodation preferences by the participants were as follows: $8.3 \%$ stay at hotels, $4.4 \%$ at hostels, and $0.6 \%$ stay at hostels and another $0.6 \%$ stay in tents/on campsites, $2.7 \%$ rent a house, $23.2 \%$ stay with acquaintances/relatives and the remaining $49.7 \%$ prefer other types of accommodation. Approximately $10.5 \%$ of the participants did not reply to this question.

In response to the question regarding the budget allocated for the trip, $74 \%$ of the participants stated that they would spend less than $500 \mathrm{TL}$ during their trip, 14\% between 500 and $1,000 \mathrm{TL}, 5 \%$ from 1,000 to $2,500 \mathrm{TL}$, and the last $4 \%$ more than 2,500 TL. Three per cent did not answer the question. Excluding accommodation and travel expenses, the average expenditures for food and drink and shopping was calculated as 280 TL and accommodation as 61 TL per person per day.

Another question in the survey was about the sources of information that motivated them to choose Tarakli as a destination. Most of the respondents $(76 \%)$ replied that they based their decision on recommendations by family/friends, a remarkable factor.

In reply to the question regarding the frequency of their visits to Tarakl1, 40.3\% indicated they had visited it for the first time and $50.3 \%$ had done so twice or more often. The latter group noted some changes in Tarakl1 between their visits. For example, they stated that as a result of the opening of thermal facilities, accommodation facilities had improved quantitatively and qualitatively; restoration work had improved the aesthetic quality of the buildings, and the number of tourists had increased in the meantime. On the other hand, some participants stated that there was no change; rather, there had been incongruent architectural changes which disrupted the silhouette of the city since their previous visit. Some positive and negative comments made are as follows:

There has been a significant increase in mobility and human circulation in the region with the opening of the hotel (K.9).

It has become a more organised area as a result of changes to accommodation and food and beverage culture and restoration (K.20).

It has become faster and more active after the thermal spa investments (K.33).

The contribution to health tourism has increased by means of the thermal facilities built in Tarakl which is a significant gain for both the public and Tarakl (K.83).

In short, I reckon that it has developed and the number of domestic and foreign tourists has increased (K.160).

I was not pleased to see aluminium balustrades, which are incongruent with the historical tissue of the city, and similarly stair rails, irrelevant frames, etc. (K.144).

When the reason for choosing Taraklı as a tourist destination was considered, it was observed that traditional architecture is the strongest attraction among visitors. This is followed by cultural activities, proximity to place of residence, local food products, the popular nature of the district, ease of transport and affordable prices, respectively. The percentage of those who stated that they preferred Taraklı because it is a slow city was found to be $25 \%$ (Table 1 ). When the question is put forth to tourists regarding the problems Taraklı is facing , $41 \%$ of the participants responded by indicating the scarcity of places for sightseeing. However, $31 \%$ people stated that there was a 
Table 1. Factors affecting the choice of Terakl1 as a preferred tourist destination.

\begin{tabular}{|c|c|c|}
\hline & Frequency & Percentage $(\%)$ \\
\hline Traditional architecture & 134 & 74 \\
\hline Desire to be within natural life & 80 & 44 \\
\hline Cultural attractions & 69 & 38 \\
\hline Proximity to residence & 47 & 26 \\
\hline A slow city & 45 & 25 \\
\hline Local food products & 40 & 22 \\
\hline Popular destination & 25 & 14 \\
\hline Easy access & 23 & 13 \\
\hline Other & 21 & 12 \\
\hline Affordable rates of accommodation, transport, food \& beverage etc. & 14 & 8 \\
\hline
\end{tabular}

*Participants were advised that they could choose more than one option.

Source: own study.

small number of food and beverage enterprises, while $25 \%$ mentioned the scarcity of activities related to cultural and natural life and the remaining $22 \%$ thought that there were not enough accommodation facilities in the town.

According to the results of the survey, $81.2 \%$ of the respondents regarded Taraklı as a slow city, while $9.4 \%$ said it was not. Around 9.4\% stated that they were not sure. As to whether their trip to Taraklı met their expectations, 88\% of participants answered affirmatively, 10\% negatively and the remaining $2 \%$ did not answer the question. Those saying 'no' justified their answer by referring to infrastructure problems, insufficient activities and inadequate information signs.

According to the survey, $95 \%$ of the respondents said that they would visit Taraklı again, whereas $4 \%$ stated the opposite. The remaining $1 \%$ left the question unanswered. The respondents who were not willing to make another visit gave the following reasons:

There's nothing to do (K.7).

I saw all the places to see (K.79).

Why should I come for the 2nd time? There are 81 provinces, in every province a thousand beautiful things to see (K.129).

It does not meet our expectations (K.151).

To the question whether Taraklı having the status of a Cittaslow city had affected tourism, most of the respondent answered positively. Some respondents thought it had a negative effect, or it might vary from person to person, or it was dependant on wishes and needs. Those on the positive side gave the following justification for their opinions:

It has been affected positively as it is located in a warm environment where people are away from environmental pollution and traffic (K.6).

Most people are looking for a place to relax and chill out in nature away from the busy pace of the city at the weekend. Therefore, it is preferred as the first choice in rank (K.9).

It increases the number of tourists by attracting people who are fed up with fast-paced life (K.34).

It has been affected positively. One avoids city life and enjoys natural life (K.97).

There is very little space left that is green and natural in our country. That's why people want to see places like this. It is affected positively (K.111).

It will attract attention and tourism mobility will increase as it has the reputation of 'slow city', I believe (K.50).

The participants who thought that tourism was negatively affected and their views were as follows:

It is negatively affected because there is little trading in a slow city. There would be little tourism as it is a difficult destination to reach (K.14).

It would lose its attractiveness for the young population (K.40). 
I was thinking negatively, but seeing Taraklı as an example of a slow city, I changed my mind (K.76).

It would not draw the attention of adventure lovers (K.95).

The participants who believed that the impact would vary depending on desires and needs gave the following explanations:

\author{
It depends on what people want who would prefer \\ this city (K.5).
}

It may vary according to the expectations of tourists. It positively affects those who want a trip which meets the slow city criteria (K.131).

It's all about the expectations of the person. Personally, I'd look for quiet places to visit with local foods (K.139).

It varies person to person (K.140).

\section{Qualitative results}

\section{Results regarding socio-economic status}

The development of slow tourism as a result of Taraklı gaining the status of a Cittaslow is positively viewed by the local people. This in turn has contributed to the growth of existing enterprises by pushing up demand and also improved the economic indicators of locals by introducing new employment opportunities. It is also seen that while the status of a slow city encourages economic growth, this does not apply to the whole local population; rather, it is being selective only. It is possible to distinguish two main groups that benefit more from this improvement. The first group is those engaged in the production and sale of touristic products and the other group is women.

Since Taraklı became a slow city, the number of incoming tourists has increased and has brought a quantitative and qualitative improvement in terms of the needs of tourists for accommodation and food and beverages, such as cafes and restaurants. In addition, the municipality has set up stands and promotional tables in areas open to local people and restored old houses offering a stage for those people to market their own products. Products in these places mainly include combs, which are the symbol of Tarakl1 town, homemade eatables and decorative objects peculiar to the city. The group which receives the highest economic gain from slow city status is composed of those who run a business in these sectors. In other words, we cannot say there is an improvement in sectors that do not directly handle the needs of tourists.

It didn't affect me because I don't sell any products that would attract tourists. I run a chicken shop (K.8).

After becoming a slow city, it did not make any change to the income of households. Only some people earned additional income. Exhibitors and shopkeepers benefited from the slow city status (K.3).

There was not much change in my household, because we do not have a profession which brings income from tourists coming to Tarakl. I am a tailor, and I mostly meet the needs of Tarakl people. Outsiders have not come to the shop so far. As a result, the people of Tarakl contribute to my earnings. The increase in the income of Tarakl people does not increase the money entering my household because those who walk into my shop are often people of low economic income from villages around Tarakl. They come to me to make salwars (baggy trousers) for them (K.4).

The other prominent group of economic beneficiaries is the women in the district. It was pointed out by all participants that women in this town had limited labour force participation and no income-generating avenues in the past. Today, however, women in Tarakli enjoy the opportunity of marketing their handicrafts, which leads to an increase in both individual's and household's income. Furthermore, they also have the opportunity to participate more actively in social life. In this regard, it is possible to say that women are better represented in the public domain in the district.

In general, women have come to the fore in social life. Upon opening and running shops, women's communication developed and they entered trade. They came into social cultural interaction with the tourists coming to the district. Women started to change the stagnation of the district and they succeeded in socialising more actively and being more entrepreneurial (K.3). 
The biggest change has especially been in ladies' social life; while they did not even go out for shopping in the district before, they now began to trade (K.2).

It has created a greater economic contribution for women, because women started making food in their homes, such as tomato paste and tarhana (soup powder), and rented the municipality's shops, where they began to make sales (K.4).

When Tarakli became a slow city, the town has received prominence and, what is more, two thermal facilities were built in the district. Therefore, efforts to develop thermal tourism in addition to slow tourism helped in encouraging new investments.

As a result of the slow city status, the increase in the number of tourists gave the opportunity to local people to get into contact with a variety of cultures. This was noted as one of the most striking outcomes, along with employment and income growth, because cultural exchange accompanied by trading helped widen people's perspective on innovation and acceptance, in line with communicating with new people.

Our behaviour has also changed. Thanks to social activities, as the number of tourists coming to the city increased, people became less introverted. Everyone started walking around more comfortably. It has made a positive impact on social lives and made people more open-minded (K.5).

What has changes, in particular, is trade. Moreover, people's point of view: people can get used to anything. What used to be condemned before by saying 'Look at this, look like this!' is now considered normal by people. In other words, people have become a little more outgoing and more open to everything (K.6).

In spite of all these developments, the inhabitants of Tarakl1 think that the district would develop, even if it was not granted the title of slow city. Their thinking is based on the features such as availability of thermal facilities, the presence of Ottoman architecture and the natural beauty of the region.

\section{Results regarding the environment}

As Taraklı was granted slow city status, the fact that improvements were made in transport-oriented services such as roads and parking to cater to tourists' needs is considered an important step in environmental development by the locals. However, inadequate parking areas are still recognised as a major problem. Furthermore, participants stated that when infrastructure works were under progress, they caused environmental pollution and also disrupted daily life.

The study's participants largely agreed that environmental regulations improved the quality of urban space, namely, the quality of life. The environmental development most emphasised by the local respondents was the restoration of historical buildings which were the most important assets of Tarakl1 for becoming a slow city. They also think that this made a contribution to the socio-economic development of the city. After restoration, the houses were transformed into small shops for selling local products and accommodation establishments through which locals got jobs. Also, the improvement of old and unused parks, green areas and the construction of new ones are seen as important environmental steps among the district's residents. On the other hand, two participants stated that, during such works, some of the green space was lost to concrete buildings and this spoiled the traditional identity of Tarakl1. Apart from that, one participant said that noise pollution increased in the town because of the increased number of tourists, and the statement is as follows:

However, the population has increased and therefore a polluted environment has emerged with the incoming people. As the crowds grow, noise, that we are not accustomed to in Tarakl, is increasing too. This disturbs its natural structure a bit (K.4).

Although several negative effects on the environmental quality were reported by some participants, one of them explained this situation as being due to changed perceptions, as given below:

To be frank, we now resent places that were not notable for use in the past, wishing for new places or facilities (K.6).

It could be argued that the most important development in the environmental sense is the increase in awareness of local people about these values: 
In the environmental sense also, it has made us more careful. It enabled us to realise that we need to use the environment more regularly, more cleanly, and more carefully (K.5).

\section{Discussion}

It is a fact that tourism is a sector that contributes to policies and practices aimed at increasing human well-being at local, regional and national levels (Rogers 2008; Lee, Taylor 2005; Dwyer et al. 2004). Through a reductionist approach, three areas could be discussed which are supported by slow tourism, which are the subject of this research: economy, socio-cultural structure and the environment. In particular, these components also constitute the basic philosophy of the Slow Food movement which is a part of the Cittaslow philosophy. Based on this point of view, it also seems possible to make various observations on these three areas, since they are considered to have been boosted by tourism in Taraklı which is the study area and further the three components of sustainability.

Tourism accelerates economic growth through direct and indirect effects (McKinnon 1964). This activity, which is an alternative export model on a macro scale, acts as an intermediary for the transfer of income from developed countries to underdeveloped ones (Vegenas, Croes 2007). Similarly, it is influential in redistributing income as it mediates interregional money transfers on a smaller scale. In this sense, the fact that Cittaslow status is an important motivation factor, especially in slow tourism, increases the income of the district obtained additionally from tourism. Therefore, it can be considered a way for distribution of income on a national scale and mitigation of inequality. When the total number of tourists and daily spending amount per capita were calculated in the study area, it was found that tourists spend a total of $\$ 5,063,291$ per annum for foods and drinks, shopping, and accommodation, with $\$ 1,103,074$ especially for accommodation. Taking into account the expenses for accommodation, food and beverages, and shopping all together, it is seen that a contribution of $\$ 6,166,365$ is the additional amount to the local economy. The study conducted by Bird (2011) showed that the Charleston Wine and Food Festival, 'a dine out festival', in the United States in 2011 provided a record-breaking economic contribution of USD 7.3 million to the local economy that year.

Similar to the above-mentioned results, the findings in our study also imply that slow tourism contributes greatly to the local economy. This is quite a surprising result because, above all, the number of tourists participating in slow tourism is not as high as in mass tourism. For this reason, before analysing the research data, it was thought that the income obtained from tourism in the city would be low. However, the findings indicate the opposite. We had the initial idea of taking into account the small number of tourists and found that a considerable portion of the visitors made day trips only. It was predicted that the arrival of tourists into the slow city from neighbouring cities would have a minimal effect on spending, mainly on accommodation. Furthermore, a significant number of visitors stated that they come to visit their acquaintances/friends in the area. In other words, the town itself did not seem to be a source of motivation alone. Hence, it was expected that these people would choose to stay in the homes of the people they visited. Conversely, the findings revealed that our predictions were not correct because slow tourism contributed significantly to the local economy.

Normally, tourists demand certain goods and services such as accommodation, eating and drinking, transport and entertainment. These demands lead to the emergence of new employment opportunities and thus are considered to play an active role in sectors producing goods and services for the tourism industry (Marin 1992; Ashley, Mitchell 2006). The study area in our research is no exception since there has been an increase in the number of catering and accommodation establishments in parallel to being granted the status of Cittaslow and the increasing number of visitors in the period following the start of slow tourism movements. This has helped fight against unemployment and poverty in the region, which was indicated by all participants of the local people.

However, this situation shows a distinctive characteristic, suggesting that women benefit more from the increase in employment. In addition to the increase in women's economic welfare, the increase in their participation in the public sphere and their representation can be interpreted as an important step towards development 
in the social dimension. The fact remains, however, that women's relationship with the public sphere has always been characterised by tension in Turkey. This is because women being in the public domain are perceived as a threat to the social order which is based on the influence of religious and traditional beliefs (Tuncer 2015; Cantek et al. 2014). Bearing this in mind, it can be argued that there are important and promising developments in the struggle against social poverty thanks to the developing slow tourism movements in the area of this study.

Pablo-Romero and Molina (2013) acknowledge the impact of tourism on national and local economic development and defend this ability as arising from its integration with other types of tourism. Our study area seems to bear important potential in this regard because another Cittaslow, Göynük, is adjacent to the Taraklı district. This offers a complementary destination for slow tourism on a regional scale. In addition, the prevalence of thermal facilities in the district also allows for slow tourism to be carried out together with health tourism.

Many researchers have stated that tourism contributes to development by encouraging construction of new infrastructure and the improvement of the existing infrastructure; at the same time, well-developed infrastructure systems encourage tourism (Pablo-Romero, Molina 2013; Crouch, Ritchie 1999; Gearing et al. 1974; McElroy 2003). In our research area, improvements were made in the infrastructure and public services indicators, mainly transport and others such as green areas and sewer systems, during and after being awarded Cittaslow status. These can be mentioned as marked developments for improving the quality of both the environment and district residents.

One of the features that make the study area extraordinary is that it has beautiful examples of traditional Ottoman architecture. During the application process for acquisition of Cittaslow status, these houses were renovated and opened to local people and tourists. So, it can be stated that an important step has been taken towards the preservation of cultural heritage, which is one of the main objectives of sustainable life and development philosophies. Moreover, works carried out by the public training centre have resumed production of woven fabric, an item peculiar to
Taraklı town. These activities are aimed at preserving and promoting cultural heritage, and they are also carried out by women, which creates an alternative income for them.

Analysis of the sense of place is an integral part of tourism research because it provides an insight into the layers of meaning for the authenticity of each space (Han et al. 2019). These facts related to the sense of place of tourism destinations are recognised as the driving force behind the development of tourism because of allowing tourist destinations to improve their features and create a unique identity (Aktaş 2016). At this point, it may be useful to refer to the locals' feelings about the value of 'place' where they live. We suggest this based upon some interviewees' comments. They told us that they had not been aware of the value of Taraklı before and, recently their love and attachment to this place had grown during the process of becoming a Cittaslow.

\section{Conclusion}

After Taraklı was granted the status of Cittaslow, the number of tourists visiting Tarakl1 had increased. The increased number of visitors has in turn improved employment opportunities for the local population and ultimately brought about positive outcomes by means of income increase. In addition, the new status has increased the social welfare of the local residents, mainly women. Moreover, traditional lines of business have been revived and Cittaslow has played an instrumental role in preservation of cultural heritage through restoration works. Other notable outcomes such as the improved quantity and quality of green space in the town in the context of environmental sustainability are among the main goals of sustainable development.

This research confirms that many improvements had taken place in the city in social, economic and environmental terms thanks to slow tourism after Taraklı became a slow city. Although this is of great importance for the well-being of the local people, it carries a number of problems that are in conflict with the Cittaslow philosophy itself. One of these is the danger of over-tourism. A fast-paced lifestyle increases the interest day by day towards slow destinations as well as slow movements (Wilson, Hannam 2017; 
Losada, Mota 2019). Therefore, rather than increasing the number of tourists, the main goal in planning tourism in slow cities should be optimal planning in line with Cittaslow's principles.

As a conclusion, this study was carried out with the intention of investigating the relationship between the status of Cittaslow, slow tourism and sustainable development. It was found that the slow city movement and tourism can be considered as an alternative model for sustainable development. Based on the results, it can be stated that Cittaslow status and the accompanying improvements are not a myth as proved in the case of Tarakl1 without any doubt.

\section{Future studies}

Cittaslow certification of cities is effective in increasing the well-being of the local people. However, there is a threat of slow tourism turning into over-tourism. This assumption might be addressed in future studies.

The slow city movement is found to be much more effective in increasing the well-being of certain groups within the local population and the most remarkable group is women. Future studies could investigate the association between Cittaslow certification and women's participation in both labour and public life.

\section{Acknowledgements}

We thank the municipality of Taraklı for their contribution to the research.

\section{References}

Aktaş S.G., 2016. Serbest Zaman, Seyahat ve Turizm (Leisure, Travel and Tourism). In: Aktaş S.G. (ed.), Turizm Coğrafyası Kitabı Içinde (Tourism Geography). Anadolu Üniversitesi Yayınları, Eskișehir: 3-36.

Ashley C., Mitchell J., 2006. Can tourism reduce poverty in Africa? Overseas Development Institute (ODI) Briefing Paper. London, UK.

Aslan E., 2015. Sakarya-Taraklı Örneğinde Avrupalı Seçkin Destinasyonlar (EDEN) ve Sürdürülebilir Turizm (European destinations of excellence (EDEN) and sustainable tourism: The Sakarya-Taraklı case), Atılım Üniversitesi, Sosyal Bilimler Enstitüsü, Yayınlanmamış Yüksek Lisans Tezi.

Baldemir E., Kaya F., Şahin T.K., 2013. A management strategy within sustainable city context: Cittaslow. Procedia-Social and Behavioral Sciences 99: 75-84.
Başarangil İ., Ulaş Ş., 2017. A research on the perceptions, attitudes and life satisfaction of the Cittaslow citizens sample of Vize county. International Journal of Business and Social Science 8(1): 107-116.

Batyk I., Woźniak M., 2019. Benefits of belonging to the Cittaslow network in the opinion of residents of member cities. Economic and Regional Studies/Studia Ekonomiczne i Regionalne 12(1): 56-67.

Bauman Z., 2012. Küreselleşme, Toplumsal Sonuçları (Globalisation, social consequences). Çev. Abdullah Yılmaz, Ayrintı Yayınları, İstanbul.

Bekar A., Yozukmaz N., Sürücü Ç., Gövce A.M., 2015. The concept of Cittaslow as a marketing tool for destination development: The case of Muğla, Turkey. American International Journal of Social Science 4(3): 54-64.

Bird A., 2011. Wine + Food = Record Year: Event's Economic Impact Highest Ever, Analysis Finds. Online: https:// www.crda.org/news/local_news/wine-food-recordyear-events-economic-impact-highest-ever-analysisfinds/ (accessed: 10 January 2020).

Botta M., 2016. Evolution of the slow living concept within the models of sustainable communities. Futures 80: 3-16.

Cantek F.Ş., Ulutaş Ç.Ü., Çakmak Ş., 2014. Evin İçindeki Sokak, Sokağın İçindeki Ev: Kamusal ile Özel 'ara'sında Kalanlar (The street inside the house, the house inside the street: People remaining between public and private). In: Cantek F.Ş. (ed), Kenarın Kitabı:'Ara'da Kalmak, Çeperde Yaşamak içinde (The book of the edge: Staying between, living on the edge). İletişim Yayınları, İstanbul: 121-159.

Çavaç Z., 2008. Sakarya İli Taraklı İlçesinde El Sanatları Ve Zanaatları (Hand crafts and arts specific to Taraklı a district of Sakarya), Sakarya Üniversitesi, Sosyal Bilimler Enstitüsü, Türk Dili Ve Edebiyatı Anabilim Dalı, Yayınlanmamış Yüksek Lisans Tezi.

Creswell J., 2009. Research design: Qualitative, quantitative, and mixed methods approaches. SAGE Publications, London.

Creswell J.W., Clark V.L.P., 2007. Designing and conducting mixed methods research. SAGE, Thousand Oaks.

Crouch G.I., Ritchie J.R.B., 1999. Tourism competitiveness and societal prosperity. Journal of Business Research 44(3): 137-152.

Daly K.J., 2001. Introduction: Minding the time: Toward a theoretical expansion of time in families. In: Daly K.J. (ed.), Minding the time in family experience: Emerging perspectives and issues (1st Ed., Vol. 3). JAI, Amsterdam; New York.

Değirmenci İ., Sarıbıyık M., 2015. Tarihi Mekanlarda Sürüdürülebilirlik Bağlamında Cittaslow Hareketi: Taraklı Örneği (Cittaslow movement at historical places in the context of sustainability: Example of Tarakl1), 2nd International Buildings Symposium, 612-620, Ankara, Türkiye.

Dickinson J.E., Lumsdon L.M., Robbins D., 2011. Slow travel: Issues for tourism and climate change. Journal of Sustainable Tourism 19(3): 281-300.

Doyduk H.B.B., Okan E.Y., 2017. Sustainable city branding: Cittaslow - the case of Turkey. In Advertising and Branding: Concepts, Methodologies, Tools, and Applications. IGI Global: 1013-1032.

Dwyer L., Forsyth P., Spurr R., 2004. Evaluating tourism's economic effects: New and old approaches. Tourism Management 25(3): 307-317.

Ekinci M.B., 2014. The Cittaslow philosophy in the context of sustainable tourism development; the case of Turkey. Tourism Management 41: 178-189. 
Gearing C.E., Swart W.W., Var T., 1974. Establishing a measure of touristic attractiveness. Journal of Travel Research 12(4): $1-8$.

Hall C.M., 2006. Introduction: Culinary tourism and regional development: From slow food to slow tourism? Tourism Review International 9(4): 303-305.

Han J.H., Kim J.S., Lee C.K., Kim N., 2019. Role of place attachment dimensions in tourists' decision-making process in Cittáslow. Journal of Destination Marketing $\mathcal{E}$ Management 11: 108-119.

Harvey D., 1989. The condition of postmodernity: An enquiry into the origins of cultural change. Oxford Blackwell.

Heitmann S., Robinson P., Povey G., 2011. Slow food, slow cities and slow tourism, In: Robinson P., Heitmann S., Dieke P. (eds), Research themes for tourism. CAB International, Wallingford: 114-127.

Hekimci F., 2014. Sürdürülebilir Bir Yerel Kalkınma Modeli: "Yavaş Şehirler" Ve Ekoturizm (Sustainable Local Development and Slow Cities). Kalkınmada Anahtar Verimlilik Dergisi, T.C. Bilim Sanayi Ve Teknoloji Bakanlı̆̆ı, Verimlilik Genel Müdürlüğü (Republic of Turkey, Ministry of Science, Industry and Technology, General Directorate of Productivity), Ankara.

Howard C., 2012. Speeding up and slowing down. In: Fullagari Markwell and Wilson (eds), Slow tourism: Experiences and mobilities. Channel View, Bath UK: 11-24.

Kan H., 2009. Taraklı Yerleşimindeki Tarihi Dokunun Sürdürülebilirliği Bağlamında Kentsel Koruma ve Geliştirme Stratejileri (Urban conservation and development strategies for sustainable historical heritage in Taraklı), Bartın Üniversitesi, Fen Bilimleri Enstitüsü, Peyzaj Mimarlığı Anabilim Dalı, Yayınlanmamış Yüksek Lisans Tezi.

Karabă̆ O., Yucel F., İnal M.E., 2012. Cittaslow movement An opportunity for branding small towns and economic development in Turkey. International Journal of Economics and Research 313: 64-75.

Lee C.K., Taylor T., 2005. Critical reflections on the economic impact assessment of a mega-event: The case of 2002 FIFA World Cup. Tourism Management 26(4): 595-603.

Lin L.P., 2017. Industrial tourists' behavioral intention toward slow travel in Taiwan. Journal of Sustainable Tourism 25(3): 379-396.

Losada N., Mota G., 2019. 'Slow down, your movie is too fast': Slow tourism representations in the promotional videos of the Douro region (Northern Portugal). Journal of Destination Marketing \& Management 11: 140-149.

Lumsdon L.M., McGrath P., 2011. Developing a conceptual framework for slow travel: A grounded theory approach. Journal of Sustainable Tourism 19(3): 265-279.

Marin D., 1992. Is the export-led hypothesis valid for industrialized countries? Review of Economics and Statistics 74: 678-688.

Mayer H., Knox P., 2006. Slow cities: Sustainable places in a fast world. Journal of Urban Affairs 28: 321-334.

McElroy J.L., 2003. Small Island tourist economies across the lifecycle, Paper prepared for The International Conference, Beyond MIRAB: The Political Economy of Small Islands in the 21st Century, School of Economics and Finance, Victoria University, Wellington, New Zealand, 23-25 February 2003.

McKinnon R.I., 1964. Foreign exchange constraints in economic development and efficient aid allocation. Economic Journal 74: 388-409.

Nilsson J.H., Svard A.C., Widarsson A., Wirell T., 2007. 'Slow' destination marketing in small Italian towns, $\mathrm{Pa}$ - per presented to the 16th Nordic Symposium in Tourism and Hospitality Research, Helsingborg, 2007.

Nilsson J.H., Svärd A.C., Widarsson A., Wirell T., 2011. 'Cittáslow'eco-gastronomic heritage as a tool for destination development. Current Issues in Tourism 14(4): 373-386.

Özkan S., 2008. Taraklı'nın Fiziksel ve Tarihsel Dokusu, Sivil Ve Anıtsal Mimarlık Örnekleri Hacı Rıfatlar Konağı Restorasyonu (Physical and historical properties of Taraklı, civil and monumental architecturel samples, restoration of Hacı Rifatlar mansion). Yıldız Teknik University, Institute of Science, İstanbul.

Pablo-Romero M.D.P., Molina J.A., 2013. Tourism and economic growth: A review of empirical literature. Tourism Management Perspectives 8: 28-41.

Park E., Kim S., 2016. The potential of Cittaslow for sustainable tourism development: Enhancing local community's empowerment. Tourism Planning \& Development 13(3): 351-369.

Petrini C., 2001. Slow food: The case for taste, Columbia University Press, New York.

Pink S., 2008. Sense and sustainability: The case of the slow city movement. Local Environment 13: 99-106.

Presenza A., Abbate T., Micera R., 2015b. The Cittaslow movement: Opportunities and challenges for the governance of tourism destinations. Tourism Planning \& Development 12(4): 479-488.

Presenza A., Abbate T., Perano M., 2015a. The Cittaslow certification and its effects on sustainable tourism governance. Enlightening Tourism. A Pathmaking Journal, 5(1): 40-64.

Radstrom S., 2011. A place-sustaining framework for local urban identity: An introduction and history of Cittaslow. Italian Journal of Planning Practice 1(1): 90-113.

Rogers T., 2008. Conferences and conventions: A global industry (2nd Ed.). Elsevier Ltd, Burlington, MA.

Semmens J., Freeman C., 2012. The value of Cittaslow as an approach to local sustainable development: A New Zealand perspective. International Planning Studies 17(4): 353-375.

Senetra A., Szarek-Iwaniuk P., 2020. Socio-economic development of small towns in the Polish Cittaslow network-A case study. Cities 103: 102758.

Sugiyama M., Nobuoka S., 2007. From slow food to slow tourism. Tokai Women's Junior College: 1-8.

Taraklı Municipality. 2017. Taraklı'da Turizm (Tourism in Tarakl1). Online: http://www.tarakli.bel.tr/kultur_turizm.asp (accessed: June, 2017)

Tuncer S., 2015. Dışarı Çıkmak: Özelden Kamusala Feminist Bir Saha Hikâyesi (Going out: A feminist field story from the private to the public). Moment Dergi 2(2): 30-58.

UN 2015. Integrating the Three Dimensions of Sustainable Development: A Framework and Tools. Online: https:// www.unescap.org/sites/default/files/Integrating $\% 20$ the $\% 20$ three $\% 20$ dimensions $\% 20$ of $\% 20$ sustainable $\% 20$ development $\% 20 \mathrm{~A} \% 20$ framework.pdf (accessed: 28 June 2020).

Vegenas M. Sr, Croes R., 2007. Tourism, economic expansion and poverty in Nicaragua: Investigating cointegration and causal relations. Online: https://ageconsearch.umn. edu/record/7306/ (accessed: 10 January 2020).

WCED 1987. Our common future. Online: https://idl-bncidrc.dspacedirect.org/bitstream/handle/10625/152/ WCED_v17_doc149.pdf?sequence (accessed: 28 June 2020). 
Wilson S., Hannam K., 2017. The frictions of slow tourism mobilities: Conceptualising campervan travel. Annals of Tourism Research 67: 25-36.

Yurtseven H.R., Kaya O., 2011. Slow tourists: A comparative research based on Cittaslow principles. American International Journal of Contemporary Research 1(2): 91-98.
Zuzanek J., Smale B.J.A., 1997. More work - Less leisure? Changing allocations of time in Canada. Society and Leisure 20(1): 73-106.

Zuzanek J., 2004. Work, leisure, time-pressure and stress. In Haworth J.T., Veal A.T. (eds), Work and leisure. Routledge, East Sussex: 123-144. 